\title{
Analisis Postur Kerja Manual Material Handling Menggunakan Biomekanika dan $\mathrm{NIOSH}$
}

\author{
Krishna Tri Sanjaya ${ }^{(1)}$,Novi Hendra Wirawan ${ }^{(2)}$, Baid Adenan ${ }^{(3)}$ \\ ${ }^{(1,2,3)}$ Program Studi Teknik Industri,Universitas PGRI Ronggolawe Tuban \\ Email : krishnatrisanjaya80@ gmail.com ${ }^{(1)}$
}

\begin{abstract}
Abstrak
Kerja atau aktivitas merupakan salah satu kegiatan manusia yang tidak dapat dihindarkan lagi. Salah satu aktivitas tersebut adalah pemindahan barang, proses pemindahan barang terjadi baik diperusahaan maupun pekerja yang berada diluar perusahaan. Aktivitas pemindahan yang terjadi pada pekerja bongkar es balok terjadi secara manual. Aktifitas pengangkatan secara membungkuk yang disebabkan adanya pembebanan yang terlalu berat menyebabkan cedera tulang belakang dan gangguan otot lainnya (musculoskeletal disorder). Selain itu aktifitas pemindahan barang juga perlu diperhatikan guna meningkatkan kesehatan dan keselamatan kerja. Pada hasil penelitian Berdasarkan perhitungan momen gaya rata-rata adalah 74425,72 , hal ini akan membuat sakit pada tulang belakang sehingga dalam waktu tertentu tubuh akan berubah menjadi membungkuk. Nilai konsumsi energi rata-rata adalah 3,6, hal ini menunjukkan konsumsi energi oleh para pekerja termasuk kategori moderat. Untuk nilai RWL ratarata $16,42 \mathrm{~kg}$ dan nilai (LI) dengan massa beban $27 \mathrm{~kg}$ nilai LI rata-rata adalah 1,63, nilai tersebut sangat beresiko menyebabkan cedera tulang belakang L5/S1. Setelah dilakukan usulan perbaikan sistem kerja pada RWL dan LI mendapatkan hasil nilai RWL sebesar 40,67 dan LI sebesar 0,6, nilai LI setelah usulan sudah tidak menimbulkan cedera pada ruas tulang belakang L5/S1.
\end{abstract}

Kata Kunci: Biomekanika, Lifting Index (LI), Manual Material Hadling, Recommended Weight Limit (RWL)

\begin{abstract}
Work or activity is one of human activity that can not be avoided anymore. One such activity is the transfer of goods, the process of moving goods occurs both in the company and workers who are outside the company. Moving events occurring on the ice loading worker of the block occurs manually. Bending activity in bending due to overloading causes spinal cord injuries and other musculoskeletal disorders. In addition, the activity of moving goods also need to be considered in order to improve health and safety. On the results of the study Based on the calculation of the average force moment is 74425,72 , this will make the pain in the spine so that in a certain time the body will turn into bending. The average energy consumption value is 3.6 , this shows the energy consumption by the workers including the moderate category. For an average RWL value of $16.42 \mathrm{~kg}$ and a value (LI) with a load mass of $27 \mathrm{~kg}$ the mean LI value is 1.63 , the value is highly at risk of causing spinal cord injury L5 / S1. After the proposed improvement work system on RWL and LI get the results of RWL value of 40.67 and LI of 0.6, the value of LI after the proposal has not caused injury on the vertebra L5 / S.
\end{abstract}

Keyword : Biomechanics, Lifting Index (LI), Manual Material Hadling, Recommended Weight Limit (RWL) 


\section{Pendahuluan}

Aktivitas pemindahan bahan secara manual (Manual Material Handling) yang meliputi aktivitas mendorong, menurunkan, mengangkat, menarik dan membawa adalah penyebab utama keluhan karyawan di industri [1]-[3]. Naiknya tingkat cedera atau kecelakaan dapat menyebabkan sakit atau keluhan pada pekerja yang berujung pada menurunnya produktivitas kerja pekerja dan perusahaan, selain itu juga berdampak personal terhadap pekerja yang berhubungan dengan gangguan sistem kerangka otot manusia. Selain kerugian secara fisik juga menyebabkan kerugian secara materi melalui beban biaya pengobatan yang cukup tinggi dan juga ketidakhadiran pekerja serta penurunan dalam kualitas kerja. Sebagian besar pekerja dalam melakukan pekerjaannya, postur kerjanya tidak ergonomis atau tidak sesuai dengan prinsip-prinsip ergonomi yaitu tulang belakang terlalu membungkuk, jangkauan yang melebihi panjang jangkauan tangan pekerja, peralatan kerja yang kurang sesuai dengan ukuran antropometri [4]-[7]. Sehingga menimbulkan ketidaksesuaian antara pekerja dengan peralatan dan lingkungan kerjanya.Perusahaan tempat penelitian adalah sebuah perusahaan yang bergerak dalam bidang penggolahan es balok. Es balok di produksi setiap hari untuk kebutuhan konsumen yaitu untuk pendingin minuman di warung-warung atau untuk membekukan ikan-ikan hasil tangkapan nelayan selama di tenggah lautan sebelum di bahwa ke tempat pelelangan ikan ( TPI ). Dari latar belakang masalah diatas, maka yang menjadi pokok masalah untuk dirumuskan dalam penelitian ini adalah untuk merekomendasikan pola akitifitas bungkar muat es balok dengan mempertimbangkan postur kerja pengakatan dengan memberhitungan antara lain. Berapa momen gaya dan nilai konsumsi energi. Berapa nilai RWL dan LI yang seharusnya diangkat oleh pekerja, apakah pekerja beresiko atau tidak beresiko, Bagaimana usulan perbaikan terhadap pengaruh tulang belakang pada pekerja bongkar terhadap beban-beban yang diangkat selama ini. Dalam penelitian ini tujuan yang ingin dicapai yaitu untuk menentukan besarnya momen gaya dan nilai konsumsi energi pada pekerja bongkar es balok, untuk mengetahui nilai RWL (Recommended Weight Limit) dan LI (Lifting Index), untuk memberikan usulan dan mengetahui apakah aktivitas yang dilakukan oleh pekerja bongkar es balok menimbulkan resiko atau berada dalam batasan aman [8]-[10].

Biomekanika adalah ilmu yang menggunakan hukum-hukum fisika dan mekanika teknik untuk mendeskripsikan gerakan pada bagian tubuh (kinematik) dan memahami efek gaya dan momen yang terjadi pada tubuh (kinetik) [11], [12]. Biomekanika juga merupakan keilmuan yang mengombinasikan hukum-hukum fisika dan konsep-konsep teknik dengan pengetahuan dari keilmuan biologi dan perilaku manusia [11]. Mekanika dalam tubuh mengikuti hukum newton mengenai gerak, kesetimbangan gaya dan kesetimbangan. Berdasarkan prinsip biomekanika untuk menghitung besarnya momen gaya bisa dilakukan dengan cara menghitung gaya dan moment secara sebagian atau menghitung tiap-tiap segmen atau bagian yang membentuk tubuh manusia. Berat dari masing - masing segmen dibawah ini didapat dari besarnya prosentase dikali dengan gaya berat dari orang tersebut.

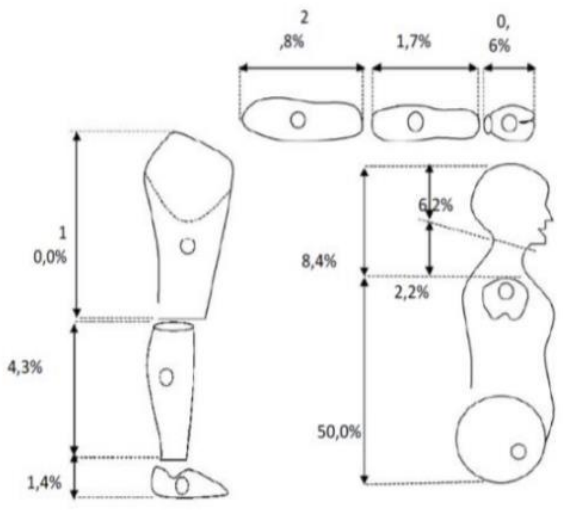

Gambar 1 Prosentase tiap segmen tubuh 
Menurut [9], [11], [12]menggambarkan tentang biomekanika statis pada tubuh ketika bekerja. Gambaran tersebut adalah perkiraan besarnya gaya tekan pada L5/S1 untuk suatu kegiatan angkatan yang spesifik. Model ini dapat juga untuk memprediksi proporsi populasi yamg akan mempunyai kekuatan pada masing-masing sambungan badan (Joint) untuk aktifitas angkat.
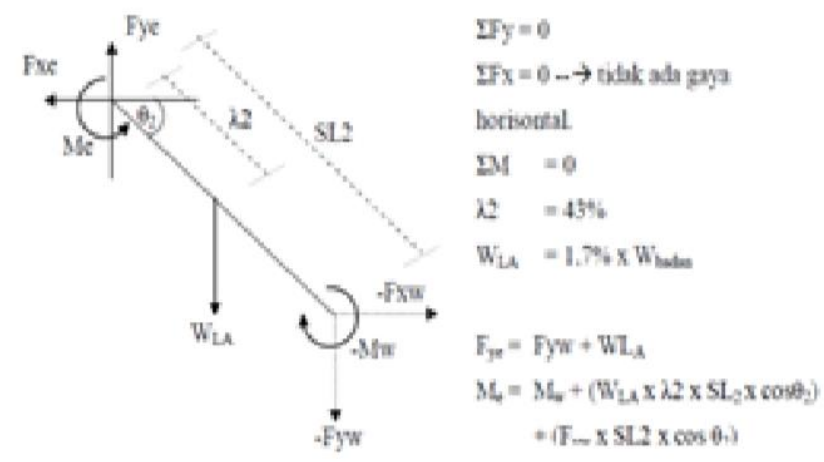

Gambar 2 Keseimbangan gaya pada telapak tangan

Keterangan :

$\mathrm{W}_{\mathrm{o}}$ = Gaya berat (Newton)

$\mathrm{W}_{\mathrm{H}}=$ Gaya berat yang diterima tangan (Newton)

$\mathrm{F}_{\mathrm{yw}}=$ Resultan gaya $(\mathrm{y})$ pada tangan (Newton)

$\mathrm{F}_{\mathrm{xw}}=$ Resultan gaya $(\mathrm{x})$ pada tangan (Newton)

$\mathrm{M}_{\mathrm{w}}=$ Resultan moment pada tangan (N.m)

$\mathrm{SL}_{1}=$ Panjang tangan $(\mathrm{m})$

$\theta_{1}=$ Sudut inkliminasi tangan relative terhadap horizontal

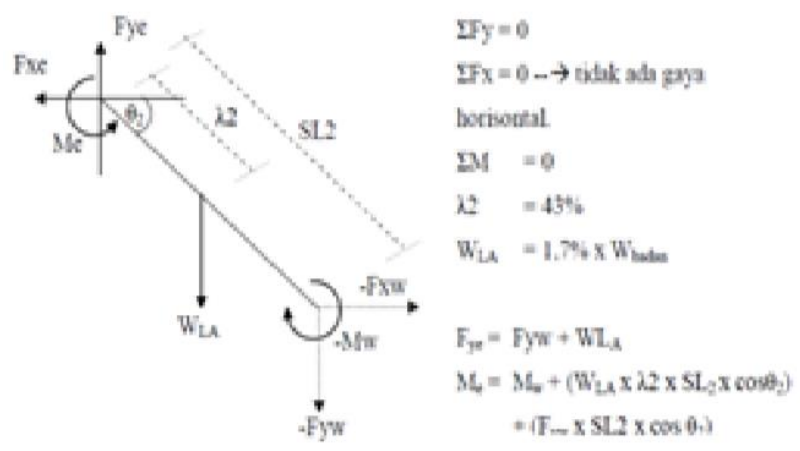

Keterangan :

$\mathrm{W}_{\mathrm{LA}} \quad$ = Gaya berat yang diterima lengan bawah (Newton)

$\mathrm{F}_{\mathrm{ye}} \quad=$ Resultan gaya (y) pada lengan bawah (Newton)

$\mathrm{F}_{\mathrm{xe}} \quad=$ Resultan gaya (x) pada lengan bawah (Newton)

$\mathrm{M}_{\mathrm{e}} \quad=$ Resultan moment pada lengan bawah (N.m)

$\mathrm{F}_{\mathrm{yw}} \quad=$ Resultan gaya (y) pada pergelangan tangan (Newton)

$\mathrm{F}_{\mathrm{xw}} \quad=$ Resultan gaya $(\mathrm{x})$ pada pergelangan tangan (Newton)

$\mathrm{M}_{\mathrm{w}} \quad=$ Resultan moment pada pergelangan tangan (N.m)

$\mathrm{SL}_{2} \quad=$ Panjang lengan bawah $(\mathrm{m})$ 
$\lambda_{2}=$ Proporsi jarak pusat masa ke siku (elbow) (43\%)

$\theta_{2} \quad=$ Sudut inkliminasi lengan bawah relative terhadap horizontal

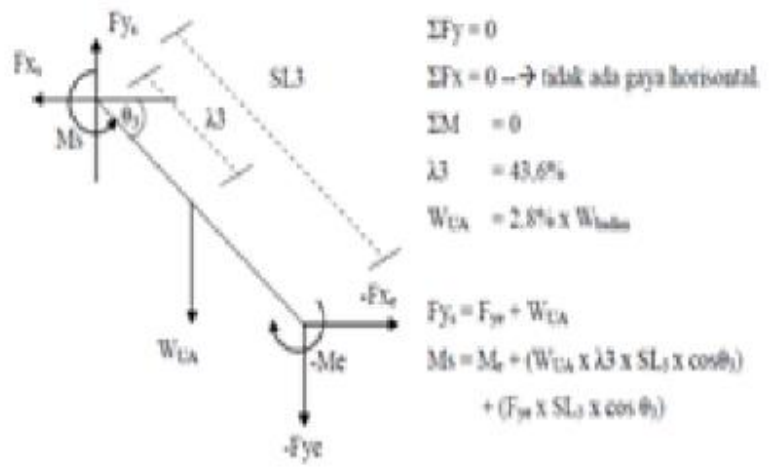

$\mathrm{NB}=$ Gaya pada lengan atas dikalikan dua, moment dikali dua agar benda utuh satu Keterangan :

$\mathrm{W}_{\mathrm{UA}}=$ Gaya berat yang diterima lengan atas (Newton)

$\mathrm{F}_{\mathrm{ys}}=$ Resultan gaya (y) pada lengan atas (Newton)

$\mathrm{F}_{\mathrm{xs}}=$ Resultan gaya (x) pada lengan atas (Newton)

$\mathrm{M}_{\mathrm{s}}=$ Resultan moment pada lengan atas (N.m)

$\mathrm{SL}_{3}=$ Panjang tangan (m)

$\lambda_{3}=$ Proporsi jarak pusat masa ke bahu (elbow) $(43,6 \%)$

$\theta_{3}=$ Sudut inkliminasi lengan atas relative terhadap horizontal

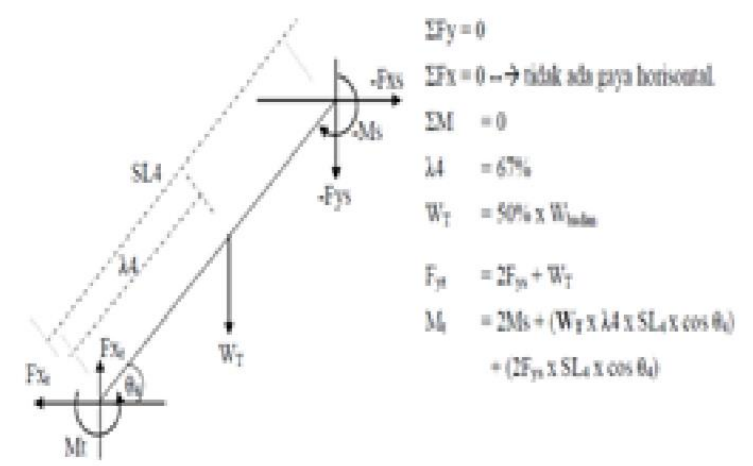

Keterangan :

$\mathrm{W}_{\mathrm{y}}=$ Gaya berat yang diterima punggung (Newton)

$\mathrm{F}_{\mathrm{yt}}=$ Resultan gaya (y) pada punggung (Newton)

$\mathrm{F}_{\mathrm{xt}}=$ Resultan gaya $(\mathrm{x})$ pada punggung (Newton)

$\mathrm{M}_{\mathrm{t}}=$ Resultan moment pada punggung (N.m)

$\mathrm{SL}_{4}=$ Panjang punggung $(\mathrm{m})$

$\lambda_{4}=$ Proporsi jarak pusat masa ke L5/S1 (elbow) (67\%)

$\theta_{4}=$ Sudut inkliminasi punggung relative terhadap horizontal

Kemudian untuk mencapai keseimbangan tubuh pada aktivitas pengangkatan, momen pada L5/S1 tersebut diimbangkan gaya otot pada spinal erector (FM) yang cukup besar. Gaya otot pada pada spinal 
erector telah dirumuskan oleh [11] sebagai berikut :

FM.E $=$ Mt - FA.D (Newton)

Untuk mencari Gaya Perut (FA), maka perlu dicari Tekanan Perut (PA) dengan persamaan :

$$
P A=\frac{10^{-1}\left[43-0,36\left(\theta_{v}+\theta_{T}\right)\right]\left[\frac{M L_{S}}{S_{1}}\right]^{1,8}}{75}\left(N / \mathrm{cm}^{2}\right)
$$

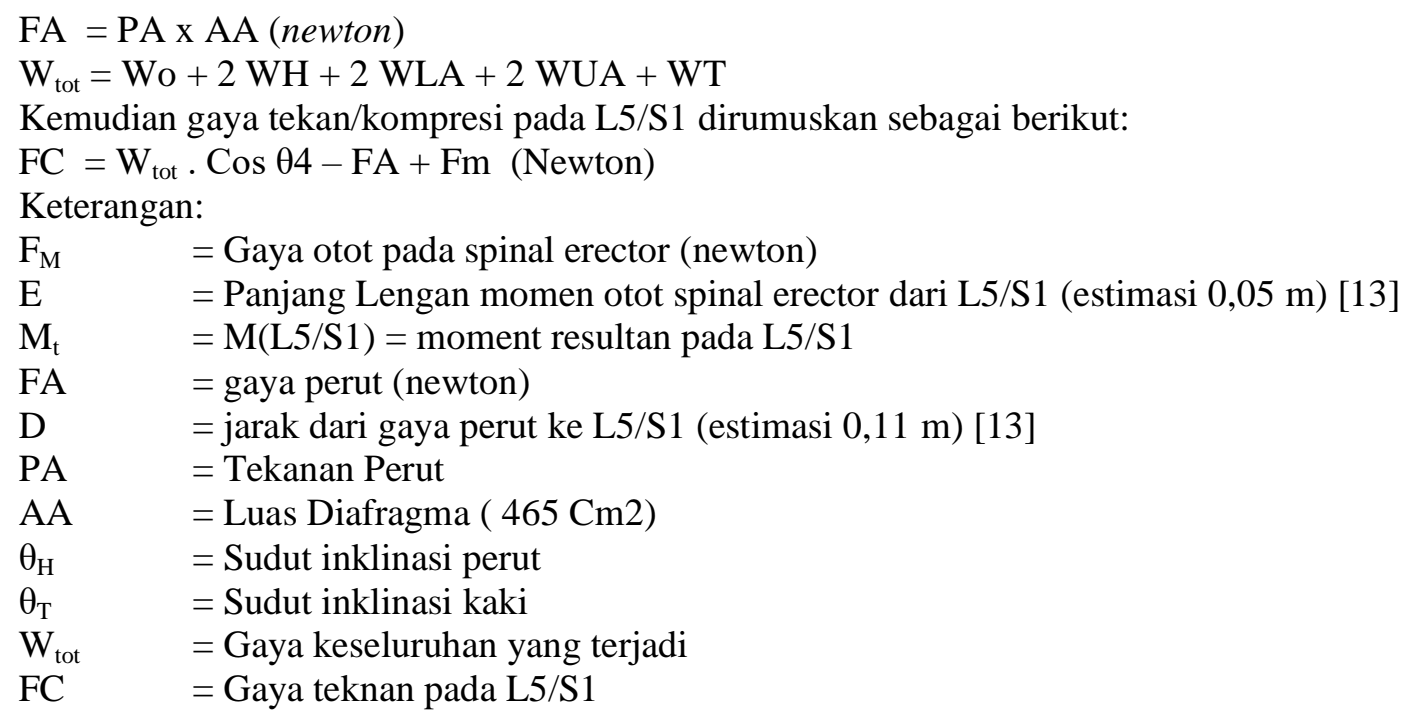

Pengukuran denyut nadi selama aktivitas bekerja adalah suatu cara untuk mengukur ketegangan cardiovasculair [9], [14], [15]. Salah satu peralatan yang dapat digunakan untuk menghitung denyut nadi adalah Heart rate monitor adalah suatu alat yang berfungsi untuk memonitor denyut jantung seseorang secara real time dengan hasil yang akurat selain itu dengan menggunakan rangsangan Electro Cardio Graph (ECG). Peralatan tersebut jika tidak tersedia, maka dapat dicatat secara manual memakai stopwatch untuk mengukur denyut nadi. Bentuk formulasi hubungan energy dengan kecepatan denyut nadi adalah regresi kuadratis dengan sebagai berikut [16] :

$$
\mathrm{Y}=1,80411-(0,0229038) \mathrm{X}+\left(4,71733.10^{-4}\right) \mathrm{X}^{2}
$$

Dimana:

Y : Energi (kilokalori per menit)

$\mathrm{X}:$ Kecepatan denyut nadi/menit

Setelah nilai denyut nadi dihitung dan dikonversikan dalam bentuk energi maka berikutnya adalah menghitung nilai konsumsi energy dengan persamaan [17]-[19]:

$$
\mathrm{KE}=\mathrm{Et} \mathrm{t}_{\text {(pengeluaran energi pada saat melakukan kerja) } \mathrm{kkal} / \text { menit }}-\mathrm{Eb}_{\text {(pengeluaran energi pada saat istirahat) kkal/menit }}
$$

Oksigen digunakan untuk pembakaran zat dalam otot yang dibawa oleh darah untuk menghasilkan energi sebagai kebutuhan umum dalam pergerakan otot.

Tabel 1 Kriteria Pekerjaan Berdasarkan Energy Expenditure

\begin{tabular}{|l|l|}
\hline Klasifikasi pekerja & Energy Expenditure (kkal/menit) \\
\hline Ringan & $<2,5$ \\
\hline
\end{tabular}




\begin{tabular}{|l|l|}
\hline Moderat & $2,5-5,0$ \\
\hline Berat & $5,0-7,5$ \\
\hline Sangat berat & $7,5-100$ \\
\hline Ekstrem berat & $>100$ \\
\hline
\end{tabular}

\section{National Institute for Occupational Safety and Health (NIOSH)}

NIOSH Lifting Index pertama kali diperkenalkan oleh NIOSH untuk aktivitas pekerjaan lifting/mengangkat. NIOSH merekomendasikan metode sederhana untuk mengukur kemungkinan terjadinya pembebanan otot yang berlebihan atas dasar karakteristik pekerjaan [2], [20]-[22]. NIOSH (National for Occupational Safety and Health) adalah suatu institusi yang menangani hal-hal yang terkait permasalahan keselamatan dan kesehatan kerja di Amerika serikat. NIOSH telah melakukan penelitian terhadap faktor-faktor beban kerja yang berpengaruh terhadap sistem biomekanika [23] [25],yaitu:

1. Berat dari beban benda yang dipindahkan.

2. Posisi pembebanan dengan mengacu pada tubuh, dipengaruhi oleh:

a. Jarak horisontal beban yang dipindahkan dari titik origin sampai destinasi

b. Jarak vertikal beban yang dipindahkan

c. Sudut pemindahan beban

3. Frekuensi pemindahan dicatat sebagai rata-rata pemindahan per menit untuk pemindahan berfrekuensi tinggi.

4. Lamanya waktu atau durasi dalam melakukan aktivitas pemindahan atau pengangkatan beban

Recommended Weight Limit (RWL) merupakan nilai rekomendasi batas angkat beban yang dapat diangkat oleh manusia tanpa alat bantu tanpa menimbulkan gangguan pada system kerangka otot manusia meskipun pekerjaan tersebut dilakukan secara berulang-ulang dan dalam jangka waktu yang cukup lama. RWL ini ditetapkan oleh NIOSH pada tahun 1991 di Amerika Serikat. Batas beban yang dapat diangkat oleh manusia tanpa menimbulkan cedera meskipun pekerjaan tersebut dilakukan secara berulang-ulang dalam durasi kerja tertentu (misal 8 jam sehari) dan dalam jangka waktu yang cukup lama. rumus untuk menghitung beban yang disarankan menurut NIOSH untuk diangkat seorang pekerja adalah [9], [14], [26], [27] :

Keterangan :

$$
\text { RWL }=\text { LC } \times \text { HM } \times \text { VM } \times \text { DM } \times \text { AM } \times \text { FM } \times \text { CM }
$$

RWL : Batas beban yang direkomendasikan

LC : Konstanta pembebanan (Lifting Constant) $=23 \mathrm{~kg}$

HM : Faktor pengali horizontal (Horizontal Multiplier) $=25 / \mathrm{H}$ dimana $\mathrm{H}$ dalam centimeter.

DM : Faktor pengali perpindahan (Distance Multiplier) $=0,82+4,5 / \mathrm{D}$ dimana $\mathrm{D}$ dalam centimeter.

AM $\quad$ : Faktor pengali asimetrik (Asymetric Multiplier $)=1-(0,0032 \mathrm{~A})$ dimana A dalam derajat.

FM : Faktor pengali frekuensi (Frequency Multiplier)

CM : Faktor pengali kopling (Coupling Multiplier)

VM : Faktor pengali vertikal (Vertikal Multiplier $)=(1-(0,003|\mathrm{~V}-75|))$ dimana $\mathrm{V}$ dalam centimeter

Setelah nilai RWL diketahui, berikutnya menghitung nilai Lifting Index, [10]. Untuk mengetahui index pengangkatan yang tidak mengandung resiko cedera tulang belakang, dengan rumus [7], [16], [28] :

$$
L I=\frac{\text { Load Weight }}{\text { Recommended Weight Limit }}=\frac{L}{R W L}
$$

Dimana $\mathrm{L}=$ Berat beban yang akan dipindahkan Keterangan : Jika $\mathrm{LI} \leq 1$, maka aktivitas 
tersebut tidak mengandung resiko cedera tulang belakang. Jika LI > 1, maka aktivitas tersebut mengandung resiko cidera tulang belakang [7].

\section{Metode Penelitian}

Obyek penelitian ini pada aktivitas pekerja bongkar muat di perusahaan yang bergerak dibidang penggolahan es balok yang bertempat di Jl. Raya Blimbing, Kec. Brondong Kab. Lamongan. Aktifitas angkat beban es balok seberat $27 \mathrm{~kg}$ secara manual yang dilakukan oleh para pekerja di pabrik penggolahan es balok. Pekerja yang diamati sebanyak 8 orang, data yang diambil meliputi berat badan pekerja, berat beban yang diangkat, panjang segmen tubuh panjang telapak tangan, lengan atas, lengan bawah, punggung, sudut inklinasi perut terhadap horizontal dan sudut inklinasi paha terhadap horizontal. Penelitian ini dilakukan untuk mengetahui beban maksimal yang diangkat oleh pekerja pengangkat es balok, mengetahui momen gaya, konsumsi energi dan denyut nadi yang nantinya digunakan sebagai penentuan batas maksimal yang dapat diangkat oleh pekerja pengangkat es balok.

\section{Pengumpulan Data}

Dalam penelitiaan ini, peneliti menggunakan 3 teknik pengumpulan data, yaitu :

1. Wawancara Yaitu salah satu dari sekiat teknik pengumpulan data yang pelaksanaannya dapat dilakukan secara langsung dengan bertanya kepada key informan. Peneliti secara langsung mewawancarai salah satu pekerja bongkar muat es balok.

2. Observasi Yaitu pengamatan secara langsung terhadap kejadian-kejadian yang ditemukan dilapangan. Kejadian ini dicatat dan didokumentasikan sebagai data penelitian. Yaitu tentang proses kerja bongkar muat yang dilakukan dengan cara manual.

3. Dokumentasi Merupakan teknik yang bisa digunakan dalam penelitian kualitatif. Dokumentasi merupakan pengumpulan-pengumpulan data berupa gambar-gambar, foto-foto, artikel, yang hasilnya dapat

\section{Pengolahan Data}

Untuk pengolahan data terdiri dari beberapa perhitungna antara lain:

1. Menghitung momen gaya pada saat bongkar muat pengangkatan es balok di nyatakan aman atau beresiko saat kerja tersebut.

2. Menghitung (KE) kosumsi energi dengan data pengukuran Denyut nadi sebelum dan sesudah kerja bongkar muat pengangkatan es balok.

3. Menghitung data RWL dan LI yang di ambil dari beberapa pengukuran yaitu, faktor pengali horizontal (HM), faktor pengali vertikal (VM), faktor pengali jarak (DM), faktor pengali asimetri (AM), faktor pengali frekuensi (FM), faktor pengali pegangan (HM).

\section{Hasil dan Pembahasan}

Data diambil aktifitas angkat beban es balok seberat $27 \mathrm{~kg}$ secara manual yang dilakukan oleh para pekerja di pabrik penggolahan es balok. Pekerja yang diamati sebanyak 8 orang, data yang diambil meliputi berat badan pekerja, berat beban yang diangkat, panjang segmen tubuh panjang telapak tangan, lengan atas, lengan bawah, punggung, sudut inklinasi perut terhadap horizontal dan sudut inklinasi paha terhadap horizontal.

Tabel 2 Data Biomekanika Pekerja Bongkar Es Balok

\begin{tabular}{|c|c|c|c|c|c|c|c|c|}
\hline Nama & Warijun & Supomo & Kastuwin & Habib & $\begin{array}{c}\text { Alam } \\
\text { Junaidi }\end{array}$ & Mustain & Wiji & $\begin{array}{c}\text { Luqman } \\
\text { Nugroho }\end{array}$ \\
\hline BB (kg) & 74 & 77 & 69 & 74 & 82 & 74 & 70 & 71 \\
\hline $\begin{array}{c}\mathrm{SL}_{1} \\
(\mathrm{~cm})\end{array}$ & 19 & 16 & 17 & 17 & 18 & 18 & 17 & 18 \\
\hline $\begin{array}{c}\mathrm{SL}_{2} \\
(\mathrm{~cm})\end{array}$ & 28 & 27 & 26 & 27 & 27 & 27 & 26 & 28 \\
\hline
\end{tabular}

Tabel 2 Data Biomekanika Pekerja Bongkar Es Balok (lanjutan)

\begin{tabular}{l|c|c|c|c|c|c|c|c|} 
Nama & Warijun & Supomo & Kastuwin & Habib & Alam & Mustain & Wiji & Luqman \\
\hline
\end{tabular}




\begin{tabular}{|c|c|c|c|c|c|c|c|c|}
\hline & & & & & Junaidi & & & Nugroho \\
\hline $\begin{array}{c}\mathrm{SL}_{3} \\
(\mathrm{~cm})\end{array}$ & 33 & 32 & 30 & 31 & 31 & 32 & 30 & 32 \\
\hline $\begin{array}{c}\mathrm{SL}_{4} \\
(\mathrm{~cm})\end{array}$ & 59 & 60 & 58 & 62 & 62 & 60 & 59 & 61 \\
\hline$\theta_{1}$ & 79 & 74 & 72 & 78 & 78 & 76 & 76 & 72 \\
\hline$\theta_{2}$ & 44 & 40 & 40 & 44 & 44 & 44 & 40 & 42 \\
\hline$\theta_{3}$ & 58 & 54 & 54 & 56 & 56 & 56 & 54 & 57 \\
\hline$\theta_{4}$ & 74 & 70 & 70 & 74 & 74 & 72 & 72 & 72 \\
\hline$\theta_{\mathrm{H}}$ & 65 & 63 & 63 & 64 & 64 & 63 & 63 & 63 \\
\hline$\theta_{\mathrm{T}}$ & 84 & 80 & 80 & 82 & 82 & 82 & 80 & 82 \\
\hline
\end{tabular}

Keterangan [11], [19]:

$\mathrm{BB}=$ Berat badan $(\mathrm{kg})$.

$\mathrm{SL}_{1}=$ Panjang tangan, jarak pergelangan tangan ke pusat masa benda $(\mathrm{m})$.

$\mathrm{SL}_{2}=$ Panjang lengan bawah, jarak pergelangan tangan-siku (m).

$\mathrm{SL}_{3}=$ Panjang lengan atas, jarak siku-bahu (m).

$\mathrm{SL}_{4}=$ Panjang punggung, jarak bahu ke L5/S1 (m).

$\theta_{1} \quad=$ Sudut inklinasi tangan relative terhadap horizontal.

$\theta_{2}=$ Sudut inklinasi lengan bawah relative terhadap horizontal.

$\theta_{3}=$ Sudut inklinasi lengan atas relative terhadap horizontal.

$\theta_{4}=$ Sudut inklinasi punggung relative terhadap horizontal.

$\theta_{\mathrm{H}}=$ Sudut inklinasi badan terhadap horizontal.

$\theta_{\mathrm{T}}=$ Sudut inklinasi kaki terhadap horizontal.

AA $=$ Luas diafragma perut $(465 \mathrm{~cm} 2)$ (Nurmianto, 1996).

$\mathrm{D}=$ Jarak antara otot punggung ke L5/S1 (asumsikan 0,11 m).

Tabel 3 Rekapitulasi Hasil Perhitungan Momen gaya

\begin{tabular}{|c|c|}
\hline Nama & Gaya tekan pada L5/S1 (Newton) \\
\hline Warijun & 32092,57 \\
\hline Supono & 94402,34 \\
\hline Kastuwin & 84175,36 \\
\hline Habib & 79529,10 \\
\hline Alam Junaidi & 82038,03 \\
\hline Mustain & 63722,97 \\
\hline Wiji & 76825,13 \\
\hline Luqman Nugroho & 82620,23 \\
\hline
\end{tabular}

Berdasarkan hasil tabel 3 menunjukkan besarnya gaya tekan yang terjadi di L5/S1 pada setiap pekerja pada aktivitas bongkas es balok. Terlihat bahwa semua pekerja memiliki gaya tekan (kompresi) di L5/S1 yang melebihi batas aman yaitu $6500 \mathrm{~N}$. Berarti bahwa pekerjaan yang dilakukan melebihi batas aman, sehingga beresiko terhadap cedera tulang belakang. Apabila hal tersebut terjadi dalam waktu yang lama, maka dapat mengakibatkan rusaknya ruas tulang belakang di L5/S1.

Tabel 4 Rekapitulasi Data Denyut Jantung Para Pekerja

\begin{tabular}{|l|c|c|c|}
\hline \multirow{2}{*}{ Nama } & \multicolumn{2}{|l|}{ Energi Expenditure (kkal/menit) } & Konsumsi Energi (kkal/menit) \\
\cline { 2 - 3 } & Awal & Akhir & \\
\hline
\end{tabular}




\begin{tabular}{|l|c|c|c|}
\hline Warijun & 2,3870167 & 5,6694124 & 3,2823957 \\
\hline Supono & 2,5123357 & 6,40746431 & 3,53512861 \\
\hline Kastuwin & 2,60050027 & 6,7989037 & 4,19840343 \\
\hline Habib & 2,46966861 & 5,8486092 & 3,37894059 \\
\hline Alam Junaidi & 2,88763717 & 5,6694124 & 2,78177523 \\
\hline Mustain & 2,60050027 & 7,00028419 & 4,39978392 \\
\hline Wiji & 2,78815101 & 6,7989037 & 4,01075269 \\
\hline Luqman Nugroho & 2,60050027 & 6,60129707 & 4,0007968 \\
\hline
\end{tabular}

Tabel diatas menunjukkan besarnya energi yang dikeluarkan oleh setiap pekerja. Masingmasing pekerja ternyata memiliki energi yang besarnya masih dibawah batas yang telah ditentukan yaitu 5,0 kkal/menit. Hal itu menunnjukkan bahwa apabila ditinjau dari aspek fisiologi dalam hal ini denyut jantung, maka pekerjaan yang dilakukan masih tergolong pekerjaan yang aman dilakukan. Faktor kebiasaan dari pekerja yang melakukan pekerjaan tersebut setiap hari menyebabkan denyut jantung yang terukur tidak berubah secara signifikan. Pekerja tidak merasakan pekerjaan tersebut membuatnya memerlukan energi yang banyak, sehingga denyut jantung yang terukurpun tidak berbeda jauh dengan sebelum bekerja [16], [29]. Maka dapat disimpulkan bahwa konsumsi energi yang di keluar oleh pekerja masih dalam kriteria beban kerja moderat, itu dalam kreteria tidak menimbulkan kelelahan saat bekerja, kriteria pekerjaan berdasarkan energy expenditure dan konsumsi energi [30], [31].

Tabel 5 Rekapitulasi Data Lifting Index (LI) Pekerja

\begin{tabular}{|c|c|c|}
\hline Nama & Recommended Weight Limit & Lifting Index \\
\hline Warijun & 14,47 & 1,74 \\
\hline Supono & 16,40 & 1,64 \\
\hline Kastuwin & 17,29 & 1,56 \\
\hline Habib & 16,40 & 1,64 \\
\hline Alam Junaidi & 17,90 & 1,50 \\
\hline Mustain & 15,80 & 1,70 \\
\hline Wiji & 15,65 & 1,72 \\
\hline Luqman Nugroho & 17,49 & 1,54 \\
\hline
\end{tabular}

Dari hasil perhitungan RWL dan LI di atas bisa dilihat hasil tabel rekapitulasinya setiap pekerja bongkar es balok tampak bahwa posisi awal dan posisi akhir kurang dari beban aktual sebesar $27 \mathrm{~kg}$. Dan untuk nilai LI pada setiap pekerja bongkar es balok tampak bahwa lebih dari 1 (L1 > 1) maka pekerjaan tersebut menimbulkan resiko cedera tulang belakang L5/S1.Untuk perhitungang LI, perkerja bongkar muat es balok ada resiko untuk tulang belakang L5/S1. Hasil perhitungan nilai LI > 1 itu termasuk dalam katagori LI pekerjaan tersebut beresiko bila dilakukan terus menerus tanpa ada solusi untuk mengurangi resiko yang terjadi.

\section{Kesimpulan}

Dari hasil penelitian analisa postur kerja pada aktivitas manual material hadling menggunakan biomekanika dan niosh dapat disimpulkan sebagai berikut : Karena seluruh pekerja memiliki gaya tekan kompresi di L5/S1 yang melebihi batas aman yaitu $6500 \mathrm{~N}$. Berarti ada resiko pada tulang belakang L5/S1 [12]. Apabila hal tersebut terjadi dalam waktu yang lama, maka dapat mengakibatkan rusaknya ruas tulang belakang di L5/S1. Untuk konsumsi energi pada pekerja disimpulkan bahwa konsumsi energi yang dikeluarkan oleh pekerja masih dalam kriteria beban kerja moderat/sedang, itu dalam kriteria tidak menimbulkan kelelahan saat bekerja, kriteria pekerjaan berdasarkan energy expenditure dan konsumsi energi [31], [32]. Berdasarkan perhitungan Recommended Weight Limit (RWL) nilai RWL kurang dari dari beban aktual sebesar $27 \mathrm{~kg}$., Untuk nilai LI lebih dari 1 (LI > 1) maka masingmasing pekerja pada pekerjaan tersebut menimbulkan resiko cedera tulang belakang L5/S1. 


\section{Daftar Pustaka}

[1] M. M. Ayoub and P. G. Dampsey, "The Psychophysical Approach to Material Handling Task Design,” Ergonomic1, vol. 42, no. 1, pp. 17-31, 1999.

[2] E. Muslimah, I. Pratiwi, and F. Rafsanjani, “Analisis Manual Material Handling," J. Ilm. Tek. Ind., vol. V, no. 2, pp. 53-60, 2006.

[3] A. Muller et al., "Motion-based prediction of external forces and moments and back loading during manual material handling tasks," Appl. Ergon., vol. 82, no. July 2019, p. 102935, 2020.

[4] OSHA, "Occupational Safety and Health Administration," www.osha.gov, 2016. [Online]. Available: https://www.osha.gov/SLTC/ergonomics/.

[5] A. I. Syazwan et al., "Poor sitting posture and a heavy schoolbag as contributors to musculoskeletal pain in children: An ergonomic school education intervention program," J. Pain Res., 2011.

[6] C. Zetterberg, M. Heiden, P. Lindberg, P. Nylén, and H. Hemphälä, "Reliability of a new risk assessment method for visual ergonomics," Int. J. Ind. Ergon., vol. 72, no. March, pp. 71-79, 2019.

[7] V. Golchha, P. Sharma, J. Wadhwa, D. Yadav, and R. Paul, "Ergonomic risk factors and their association with musculoskeletal disorders among Indian dentist: A preliminary study using Rapid Upper Limb Assessment," Indian J. Dent. Res., 2015.

[8] E. R. Vieira and S. Kumar, "Occupational risks factors identified and interventions suggested by welders and computer numeric control workers to control low back disorders in two steel companies," Int. J. Ind. Ergon., vol. 37, no. 6, pp. 553-561, Jun. 2007.

[9] E. Mas'idah, W. Fatmawati, and L. Ajibta, “Analisa Manual Material Handling (MMH) dengan Menggunakan Metode Biomekanika Untuk Mengidentifikasi Resiko Cidera Tulang Belakang (Musculoskeletal Disorder)," Univ. Sultan Agung, vol. 45, no. 119, pp. 37-56, 2009.

[10] E. Mas'idah, W. Fatmawati, and L. Ajibta, “Analisa Manual Material Handling (MMH) dengan Menggunakan Metode Biomekanika Untuk Mengidentifikasi Resiko Cidera Tulang Belakang (Musculoskeletal Disorder)," Universitas Sultan Agung, vol. 45, no. 119. pp. 37-56, 2009.

[11] C. D.B and A. G.B.J., Occupational Biomechanic. New York: John Wiley and Sons Inc, 1991.

[12] D. B. Chaffin and K. S. Park, "A lonitudinal Study of low back pain as associated with Occupational lifting factors," Am. Ind. Hyg. Assoc. J., vol. 34, p. 513, 1973.

[13] E. Nurmianto, Ergonomi, Konsep Dasar dan Aplikasinya, 2nd ed. Surabaya: PT. Guna Widya, 2004.

[14] M. D. Angelica et al., "Determinants of Time Allocation across the Lifespan A Theoretical Model and an Application to the," PLoS One, 2012.

[15] D. Mayasari and F. Saftarina, "Ergonomi sebagai Upaya Pencegahan Musculoskeletal Disorders pada Pekerja," JK Unila, 2016.

[16] H. Purnomo, A. Manuaba, and W. Adisasmito, "Sistem Kerja Dengan Pendekatan Ergonomi Total Mengurangi Keluhan Muskuloskeletal, Kelelahan dan Beban Kerja serta Meningkatkan Produktivitas Pekerja Industri Gerabah di Kasongan, Bantul," Ijbs-Udayana.Org, pp. 1-2, 2006.

[17] H. Iridiastadi and Yassierli, Ergonomi suatu pengantar. PT. Remaja Rosdaya, 2014.

[18] H. Iridiastadi and Yassierli, Ergonomi Suatu Pengantar, 1st ed. Bandung: Remaja Rosdakarya, 
2015.

[19] H. dan Y. Iridiastadi, Ergonomi Suatu Pengantar, 4th ed. Bandung: PT. Remaja Rosdakarya, 2017.

[20] Tarwaka, Ergonomi Industri, Dasar-dasar Pengetahuan dan Aplikasi di Tempat Kerja. Edisi Ke-2. 2015.

[21] L. Tarwaka, Solichol, Sidiajeng, Ergonomi Untuk Keselamatan, Kesehatan Kerjadan Produktivitas. Surakarta: UNIBA PRES, 2004.

[22] NIOSH, “Applications Manual For The Revised NIOSH Lifting Equation,” www.cdc.gov/niosh, 1994. .

[23] H. Udinus, "Fisiologi Kerja (II)," II., no. Fisiologi Kerja (II), H. Udinus, Ed. Semarang: Universitas Dian Nuswantoro, 2015, p. 39.

[24] Tiara and S. Perdana, "Analisis Beban Kerja Fisiologi Pada Proses Produksi Pembuatan Rumah Boneka Dengan Pekerja Penyandang Disabilitas," Oper. Excell. J. Appl. Ind. Eng., vol. 11, no. 1, p. 98, 2019.

[25] N. Azmi, D. M. Safitri, P. Astuti, and R. Pratama, "ANALISA BEBAN KERJA MELALUI PENDEKATAN FISIOLOGIS PADA PENGEMUDI BIS TRANSJAKARTA," no. September, 2017.

[26] M. R. da Silva, G. Waclawovsky, L. Perin, I. Camboim, B. Eibel, and A. M. Lehnen, "Effects of high-intensity interval training on endothelial function, lipid profile, body composition and physical fitness in normal-weight and overweight-obese adolescents: A clinical trial," Physiol. Behav., vol. 213, no. October 2019, 2020.

[27] H. L. Morahan, C. H. C. Leenaars, R. A. Boakes, and K. B. Rooney, "Metabolic and behavioural effects of prenatal exposure to non-nutritive sweeteners: A systematic review and meta-analysis of rodent models," Physiol. Behav., vol. 213, no. October 2019, p. 112696, 2020.

[28] S. Bevan, "Economic impact of musculoskeletal disorders (MSDs) on work in Europe," Best Practice and Research: Clinical Rheumatology. 2015.

[29] A. Kristanto and S. C. Widodo, "Perancangan Ulang Alat Perontok Padi yang Ergonomis untuk Meningkatkan Produktivitas dan Kualitas Kebersihan Padi," J. Ilm. Tek. Ind., vol. 14, no. 1, pp. 78-85, 2015.

[30] Kroemer and Elbert, Ergonomics, How to Design For Ease and Efficiency. London, New York: Taylor and Francis, 1994.

[31] K. K. E. H. K. A. D. K. Hoffman, Ergonomics 3rd Edition How to Design for Ease and Efficiency. Academic Press, 2018.

[32] Kroemer, K. H.E., and A. D, Office Ergonomics. New York: Taylor \& Francis, 2001. 